\title{
Latest Jurassic-earliest Cretaceous radiolarian fauna from the Xialu Chert in the Yarlung Zangbo Suture Zone, Southern Tibet: Comparison with coeval western Pacific radiolarian faunas and paleoceanographic implications
}

\author{
Atsushi Matsuoka†*, Qun Yangł and Masahiko Takei§ \\ † Department of Geology, Faculty of Science, Niigata University, Niigata 950-2181, JAPAN \\ ₹ Nanjing Institute of Geology and Palaeontology, Academia Sinica, Nanjing 210008, CHINA \\ $\S$ Graduate School, Ni igata University, Niigata 950-2181, JAPAN \\ * To whom correspondence should beaddressed. E-mail: matsuoka@geo.sc.niigata-u.ac.jp
}

Triassic, Jurassic and Cretaceous radiolarian faunas have been reported recently from pelagic sediments in theYarlungZangbo SutureZone, southern Tibet (Matsuoka et al . 2001, 2002; Wanget al. 2002, Ziabrevet al. 2004). Thesemicropaleontological datacan contribute not only to geotectonic history but also to paleoceanographic reconstruction. TheXialu Chertis distributed in thesouth of Xigatzealong the southern margin of theYarlung Zangbo Suture Zone and represents deep marine sediments between the Indian Block and LhasaBlock. Thispaper presentsa full assemblage of a latestJurassic (Tithonian)-earliest Cretaceous (Berriasian) fauna of the Pseu dodictyomitra carpatica (KR 1) Zone (Matsuoka 1995a) in theXialu Chert and compares it with coeval radiolarian faunas in the western Pacific regions. This paper discusses the depositional site of the Xialu Chert from a paleobiogeographic point of view.

KR 1 radiolarian fauna in the Xialu Chert (Xialu fauna) is composed of about 100 species. Abundant species include Cinguloturris cylindra Kemkin and Rudenko, Emiluvia chica Foreman, Eucyrti diellum pyramis(Aita), Loopusnuda (Schaaf), Pseudodictyomitra carpatica (Lozyniak), Sethocapsa(?) subcrassitestata Aita, Sethocapsa(?) ritteni (Tan), Stichocapsa praepulchella Hori, Svinitzium pseudopuga Dumitrica, Tethysetta dhimenaensis(Baumgartner), Tethysetta usotanensis(Tumanda), and Tethysetta boesii (Parona). Dominant genera include Archaeodictyomitra, Hemicryptocapsa, Xitus, andZhamoidellum. The genera Mirifusus, Podobursa, Podocapsa, Ristola, and Syringocapsa are rare. The Vallupus group is absent and Pantanellium is not common.

Northern hemisphere Middle-latitude coeval radiolarian faunas are found in the Torinosu Group and its equivalent formations in Southwest Japan. Common species between the Xialu and Torinosu faunas are Eucyrtidiellum pyramis (Aita), Protunuma japonicus Matsuoka and Yao, Sethocapsa(?) subcrassitestata Aita, and Solenotryma(?) idhikawai Matsuoka and Yao. They were originally described as new species from the Torinosu Group. Other common species include Cinguloturris cylindra Kemkin and Rudenko, Emiluvia chica Foreman, Loopus nuda (Schaaf), Pseudodictyomitra carpatica (Lozyniak), Svinitzium pseudopuga Dumitrica, Tethysetta boesii (Parona), and Tethysetta dhimenaensis(Baumgartner).

A low-latitude earliest Cretaceous (Berriasian) fauna was reported in a rocksamplefrom theM arianaTrench. TheMariana fauna contains about 400 species and represents the most diversified radiolarian fauna among the Berriasian radiolarian faunas in the world. Dominant genera are Archaeodictyomitra, Hemi cryptocapsa, Loopus, Napora, Neorelumbra, Obesacapsula,
Podobursa, Praecaneta, Pseudodictyomitra, Saitoum, Sethocapsa, Svinizium, Tethysetta, Williriedellum, Xitus, and Zhamoidellum. One of the distinctive features of the Mariana fauna isto contain abundant pantanellid taxaincluding the Vallupusgroup. In spite of diversified nature of the Mariana fauna, species belonging to the genus Eucyrtidielum, common both in the Xialu and Torinosu faunas, have not been found so far. The genera Cinguloturris, Miriusus, Ristola, and Solenotryma arerare.

Thefaunal comparison among southern Tibetand western Pacific regions revealed that the Xialu fauna issimilar to northern hemisphere middle-latitude assemblages represented by the Torinosu fauna. On theother hand, theXialu fauna is less similar to low-latitude (tropical) assemblages represented bytheMariana fauna. This indicates that the Xialu fauna is regarded as a representative of southern hemisphere middle-latitude faunas. The depositional site of the Xialu Chert in the KR 1 time was out sideof theVallupusTerritory (Matsuoka 1995b) which isa tropical radiolarian realm in the Late Jurassic-early Cretaceous time. $A$ mirror-image provincial ism to theequator in radiolarian faunas is reconstructed for the Tethys-Pacific Ocean in thelatestJurassicearliest Cretaceoustime.

\section{References}

MatsuokaA. 1995a. Latejurassic tropical Radiolaria: Vallupusand its related forms. Palaeogeography, Palaeoclimatology, Palaeoecology 119: 35969

MatsuokaA. 1995b. Jurassic and Lower Cretaceous radiolarian zonation in Japan and in the western Pacific. The Island Arc 4: 140-53

Matsuoka A, K Kobayashi, T Nagahashi, Q Yang, Y Wang and Q Zeng. 2001. Early MiddleJurassic (Aalenian) radiolarian fauna from theXialu chert in theYarlungZangbo SutureZone, southern Tibet. In: Metcalfel, JMB Smith, M Morwood and IAA Davidson (eds.) Faunal and floral migrations and evolution in SE Asia-Australasia. Balkema, Swets \& Zeitlinger Publishers. p 105-10

Matsuoka A, Q Yang, K Kobayashi, M Takei, T Nagahashi, Q Zeng. and Y Wang. 2002. Jurassic-Cretaceous radiolarian biostratigraphy and sedimentary environments of the Ceno-Tethys: records from theXialu chert in the Yarlung Zangbo Suture Zone, southern Tibet. Jour Asian Earth Science 20. 277-87

WangY, Q Yang, A Matsuoka, K Kobayashi, T Nagahashi and Q Zeng. 2002. Triassic radiolarians from the Yarlung Zangbo Suture Zone in the Jinlu area, Zetang County, southern Tibet. Acta Micropalaeont Sinica 19: 215-27

Ziabrev SV, JC Aitchison, AV Abrajevitch, Bandengzhu, AM Davis and H Luo. 2004. Bainang Terrane, Yarlung-Tsangpo suture, southern Tibet (Xizang, China): a record of intra-Neotethyan subduction-accretion processes preserved on the roof of the world. Journal of theGeological Society 161: 523-38 